\title{
HEATING THE KNEE JOINT
}

\author{
BY \\ H. M. WHYTE and S. R. READER
}

(RECEIVED FOR PUBLICATION AUGUST 9, 1951)

It is generally conceded that radiant heat is less effective than diathermy for heating joints. We have made some observations on this point in the knee joint in the course of other studies and present here our methods and results which may be of value to those who are interested in measuring joint temperatures and assessing the effectiveness of treatment.

\section{Methods}

The left leg of one subject was used for each test. The subject was seated with the leg hanging vertically. Skin temperature was recorded with two wire thermocouples made of 30 s.w.g. constantan and 47 s.w.g. copper (Whyte, 1951) held in place by the springiness of the wire leads, which were fixed more remotely to skin with adhesive plaster. This type of thermocouple records skin temperature with less than $0.5^{\circ} \mathrm{C}$. error even in the presence of radiant heat. The intra-articular temperature was recorded with a needle thermocouple passed through an area anaesthetized with a small amount of 2 per cent. novocaine on the antero-medial side of the joint. The needle thermocouple was made of 47 s.w.g. copper and constantan wires soldered to the tip of a steel needle $0.5 \mathrm{~mm}$. in diameter (Whyte and Reader, 1951). It is accurate to $0 \cdot 1^{\circ} \mathrm{C}$. and is not affected by radiant heat. The thermocouples were connected to a reference junction in a thermos of water maintained by a heating coil at about $37^{\circ} \mathrm{C}$., and through a switch box to a galvanometer whose deflection was shown by the movement of a beam of light on a scale. The thermocouples were calibrated by water immersion; $1^{\circ} \mathrm{C}$. gave a deflection of $1 \mathrm{~cm}$.

Two sources of radiant heat were used: long-wave infra-red radiation from an 800 -watt Sollux dark-source, and short-wave infra-red radiation from a 1,000-watt tungsten filament lamp.* The intensity was measured with the thermoradiometer of Evans and Mendelssohn (1946).

Diathermy was supplied from a Siemen's "Ultratherm " apparatus operating at a fixed wavelength of 6 metres and a frequency of 50 megacycles, with a filament voltage of 20. An inductothermy coil was wound round the knee.

\section{Results}

Radiant heat was applied to the front and medial side of the knee, first $1 \cdot 0$ pyron $(1.0 \mathrm{~g}$. cal./sq. cm./min.) of long-wave infra-red for $30 \mathrm{~min}$., then after a 30 -min. rest $2 \cdot 0$ pyrons of short-wave infra-red for a further $30 \mathrm{~min}$. The results are shown in the Figure. The joint temperature fell slowly from 33.6 to $33 \cdot 2^{\circ} \mathrm{C}$. during the preliminary period of $15 \mathrm{~min}$. and then continued to fall at this rate to $32 \cdot 9^{\circ} \mathrm{C}$. in the first $10 \mathrm{~min}$. of heating, in spite of an abrupt rise of skin temperature to about $40^{\circ} \mathrm{C}$. The joint temperature then rose and continued to do

* We are indebted to Hanovia Ltd., Slough, for the loan of this lamp. 


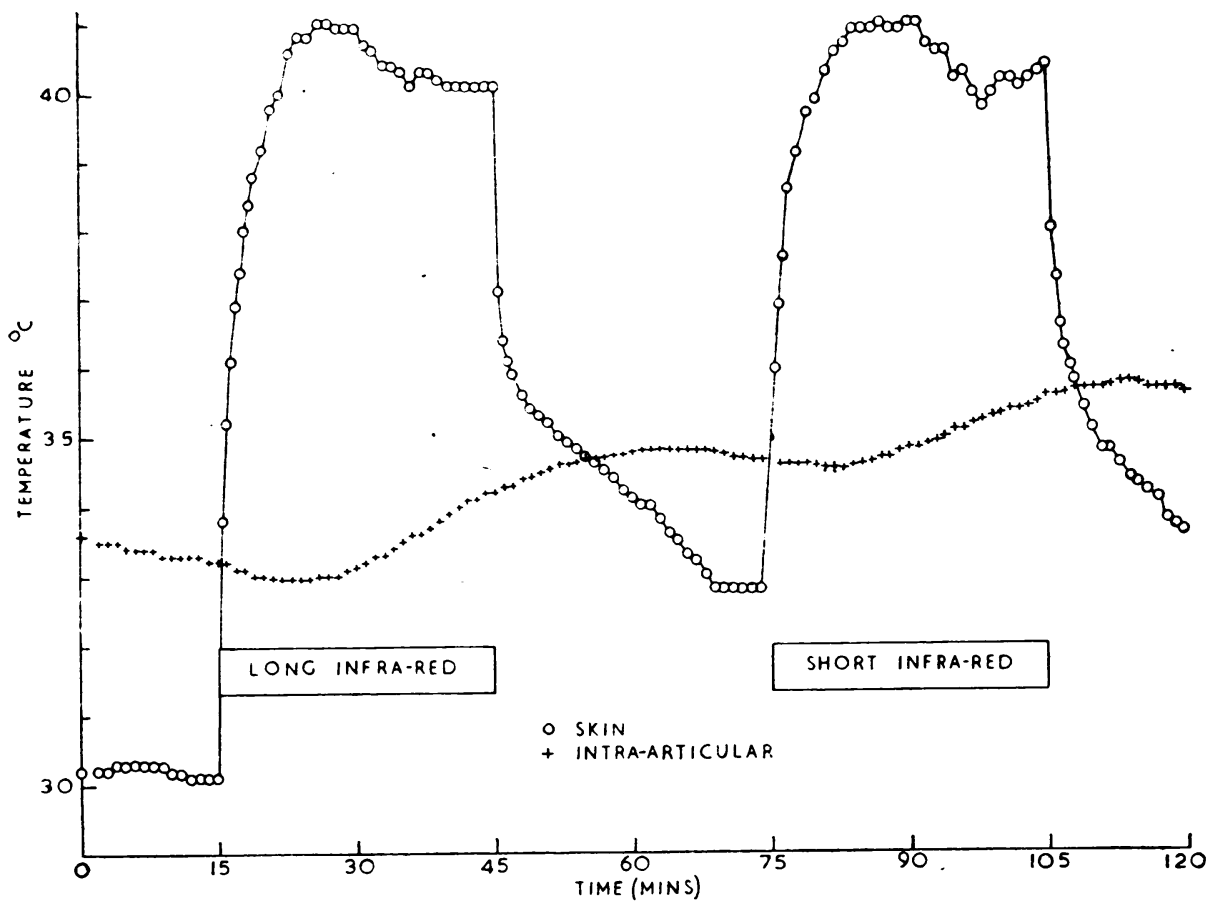

FIGURE.-Effect of application of radiant heat on skin and intra-articular temperatures of knee joint.

so for $20 \mathrm{~min}$. after the radiation had been stopped, reaching a maximum of $34.8^{\circ} \mathrm{C}$. A similar effect was produced by the short-wave infra-red radiation.

The Ultratherm was used for $30 \mathrm{~min}$. on another occasion, the thermocouples being removed during the period of heating. The initial skin temperature was $31.4^{\circ} \mathrm{C}$. The joint temperature reached its peak $6 \mathrm{~min}$. after heating was stopped. The effects of the three methods of heating are shown below:

\begin{tabular}{|c|c|c|c|c|}
\hline \multirow{2}{*}{\multicolumn{2}{|c|}{ Method of Heating }} & \multicolumn{3}{|c|}{ Joint Temperature $\left({ }^{\circ} \mathrm{C}.\right)$} \\
\hline & & Initial & Maximum & Rise \\
\hline $\begin{array}{l}\text { Long infra-red } \\
\text { Short infra-red } \\
\text { Diathermy . . }\end{array}$ & $\begin{array}{l}\ldots \\
\ldots \\
\ldots\end{array}$ & $\begin{array}{l}33 \cdot 2 \\
34 \cdot 7 \\
35 \cdot 0\end{array}$ & $\begin{array}{l}34 \cdot 8 \\
35 \cdot 8 \\
37 \cdot 7\end{array}$ & $\begin{array}{l}1 \cdot 6 \\
1 \cdot 1 \\
2 \cdot 7\end{array}$ \\
\hline
\end{tabular}

\section{Discussion -}

Diathermy is the best of the three methods used here for heating the knee joint. The fact that diathermy caused the joint temperature to rise above the normal temperature of blood is an indication of deep penetration by this form of heat. On the other hand, the delayed and poor response to radiant heat can be interpreted to mean that infra-red radiation, even of the most penetrating type such as that 
given by a tungsten filament lamp (Hardy and Muschenheim, 1936), has no direct effect on the joint. When radiation is applied to the knee the heat is absorbed by the skin and superficial tissues and is carried away by the blood without directly influencing to any appreciable extent the temperature of the underlying joint. However, the absorption of heat and the consequent increase in blood flow lead to gradual warming of the whole leg, as a result of which the temperatures throughout the limb, particularly in the centre, approach the temperature of the blood. Thus, the application of moderate amounts of heat to the whole limb is probably more efficient than applying intense heat restricted to the region of the joint when radiant heat, hot-water bottles, or other non-penetrating forms of heat are used. The most that can be hoped for with these methods is to raise the joint temperature to $37^{\circ} \mathrm{C}$. or slightly more. The most efficient heating would be given by warming the whole limb at the same time as applying diathermy to the knee.

Horvath and Hollander (1949) recorded an abrupt fall in joint temperature when hot packs were applied to the knee, and the opposite effect was produced when cold packs were used. They attributed these changes to vascular reflexes. No such changes were observed in the present study.

\section{Summary}

The changes in temperature produced by different methods of heating were measured by thermocouples.

Diathermy was more effective than either long-or short-wave infra-red radiation.

The effect of radiant heat on the joint is thought to be determined mainly by the changes produced in the whole limb.

\section{REFERENCES}

Evans, D. S., and Mendelssohn, K. (1946). J. sci. Instrum., 23, 94.

Hardy, J. D., and Muschenheim, C. (1936). J. clin. Invest., 15, 1.

Horvath, S. M., and Hollander, J. L. (1949). Ibid., 28, 469.

Whyte, H. M. (1951). Clin. Sci., 10, 325.

-, and Reader, S. R. (1951). Annals of the Rheumatic Diseases, 10, 449.

\section{Chauffage de l'articulation du genou}

\section{RÉSUMÉ}

Les variations de la température produites par de différentes méthodes de chauffage furent mesurées à l'aide des couples thermoélectriques.

La diathermie s'est montrée plus efficace que les rayons infrarouges à onde grande ou courte.

On considère que l'effet des rayons thermiques sur l'articulation est déterminé surtout par les modifications survenant dans le membre entier.

\section{Calentamiento de la articulación de la rodilla \\ Sumario}

Las variaciones de la temperatura producidas por diferentes métodos de calentamiento fueron medidas por medio del par termoeléctrico.

La diatermia se mostró más eficaz que los rayos infrarrojos de onda larga o corta.

Se considera que el efecto de los rayos térmicos sobre la articulación se debe sobre todo a las - modificaciones que sobrevienen en el miembro entero. 